\title{
Atlantic puffin diet reflects haddock and redfish abundance in the Gulf of Maine
}

\author{
Katelyn M. Depot ${ }^{1, *}$, Lauren C. Scopel ${ }^{2}$, Stephen W. Kress ${ }^{3}$, Paula Shannon ${ }^{4}$, \\ Antony W. Diamond ${ }^{2}$, Kyle H. Elliott ${ }^{1}$
}

\footnotetext{
${ }^{1}$ Department of Natural Resource Sciences, McGill University, Sainte-Anne-de-Bellevue, Quebec H9X 3V9, Canada

${ }^{2}$ Atlantic Laboratory for Avian Research, University of New Brunswick, Fredericton, New Brunswick E3B 5A3, Canada

${ }^{3}$ National Audubon Society Seabird Restoration Program, Ithaca, NY 14850, USA

${ }^{4}$ National Audubon Society Seabird Restoration Program, Bremen, ME 04551, USA
}

\begin{abstract}
Ecosystem-based fisheries management, which considers the interactions between fisheries, target species, and the physical and biological components of ecosystems, is necessary to ensure that directed fisheries avoid adverse impacts to ecosystems over the long term. The successful implementation of ecosystem-based fisheries management requires an understanding of predator-prey relationships and ways to operationalize such relationships to inform fisheries management. Here, we investigated if the diet of a generalist predator, Atlantic puffin Fratercula arctica, can be used as an indicator of the abundance of 2 commercially exploited prey species (haddock Melanogrammus aeglefinus and Acadian redfish Sebastes fasciatus) in the Gulf of Maine. Because haddock and redfish eaten by puffins are juveniles (age 0), there is potential to use their proportions and lengths in puffin diet to better understand the processes influencing haddock and redfish recruitment. By using principal component analysis to develop measures of diet across multiple puffin colonies, we show both spatial variation and large-scale patterns in the proportions and lengths of haddock and redfish in puffin diet. Spawning stock biomass was a strong predictor of haddock proportion in puffin diet and a moderate predictor of redfish proportion; however, proportions in puffin diet did not predict age-1 recruitment, suggesting that variation in recruitment is caused by processes that occur after the puffin breeding season and which affect the survival of older juveniles. Haddock length on one colony was a moderate predictor of age-1 recruitment. We conclude that puffin diet can be used as an indicator of haddock and redfish abundance.
\end{abstract}

KEY WORDS: Seabirds · Indicators · Forage fish · Ecosystem-based fisheries management · Diet · Recruitment $\cdot$ Spawning stock biomass $\cdot$ Principal component analysis

\section{INTRODUCTION}

There is increasing consensus that the maintenance of sustainable fisheries requires a shift from traditional single-species management approaches to ecosystembased approaches that consider the interactions between diverse ecosystem components (Christensen et al. 1996, Francis et al. 2007). Predator-prey relationships play a key role in structuring ecosystems. Predators respond to changes in prey abundance by changing their rates of consumption (the functional

*Corresponding author: katelyn.depot@mail.mcgill.ca

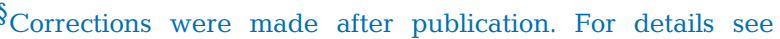
www.int-res.com/articles/meps_oa/661/m661p243.pdf

This corrected version: March 4, 2021 response; Holling 1966) and reproduction (the numerical response; Solomon 1949). Understanding the relationships between a harvested species and its predators is not only necessary to avoid depleting the stock to a level that can no longer sustain predators (Cury et al. 2011), but also provides the opportunity to use predators as indicators of prey abundance (Cairns 1988, Davoren \& Montevecchi 2003, Field et al. 2007, Hazen et al. 2019).

There is a growing body of research on the use of seabirds as indicators in fisheries management

( ) The authors 2020. Open Access under Creative Commons by Attribution Licence. Use, distribution and reproduction are unrestricted. Authors and original publication must be credited. 
(Velarde et al. 2015, Brisson-Curadeau et al. 2017, Scopel et al. 2018). Seabirds often feed on ecologically and commercially important forage fish. In addition, many species breed in large colonies where they can be observed relatively easily year after year. Because seabirds often feed on young fish that have not yet recruited to the fishery, they can provide an early source of information about cohort sizes (Cairns 1988). While seabirds show both functional and numerical responses to changes in prey density, direct measures of diet are generally better indicators than reproductive parameters (Piatt et al. 2007, Einoder 2009, Brisson-Curadeau et al. 2017, Hazen et al. 2019). In particular, a number of studies have proposed the use of puffins as indicators of forage fish availability (Hatch \& Sanger 1992, Diamond \& Devlin 2003, Cunningham et al. 2018), including in regions where there are no independent estimates of stock size or parameters (Sydeman et al. 2017, Piatt et al. 2018). Several studies have shown relationships between seabird diet composition and independent measures of forage fish abundance (Barrett 2002, Deguchi et al. 2004, Mills et al. 2007, Velarde et al. 2015, Scopel et al. 2018). In the case of Atlantic puffins Fratercula arctica, the proportions of capelin Mallotus villosus, age-1 herring Clupea harengus, and age-0 cod Gadus morhua in puffin diet were proportional to their relative estimated biomasses in Norway (Barrett 2002), and the proportion of age-1 herring in puffin diet was proportional to age-1 recruitment of herring in the Gulf of Maine (GOM) (Scopel et al. 2018). Here, we investigated relationships between Atlantic puffin chick diet composition on 4 colonies in the GOM and fishery- and survey-derived measures of haddock Melanogrammus aeglefinus and Acadian redfish Sebastes fasciatus abundance. Puffin diet (age-1 Atlantic herring) at one of the colonies has already been shown to reflect herring recruitment, although regionally, common terns Sterna hirundo showed the greatest potential for predicting herring recruitment (Scopel et al. 2018).

Haddock and redfish are harvested as part of multispecies groundfish fisheries in both US and Canadian waters. Both haddock and redfish experienced severe declines due to overfishing during the latter half of the twentieth century, but are now recovering due to successful management (NEFSC 2017). As part of the stock assessment process, annual, 1 January, estimates of spawning stock biomass (SSB) and age-1 recruits are determined for each stock from a combination of fishery-dependent and fishery-independent data. (In fisheries terminology, fish are considered 'age 0 ' during the calendar year in which they were born and become 'age 1' on 1 January of the following year. 'Age-1 recruits' refers to the number of fish surviving to join the 'age-1' age class on 1 January of a given year.) While relative year class size remains approximately constant after the first year of life, age-1 recruitment is highly variable and difficult to predict (Brodziak et al. 2001, Lapolla \& Buckley 2005). Haddock stocks in particular are characterized by episodic, extremely large recruitment events. For example, the 2013 year class of haddock in the GOM was 15 times as large as the average year class in the preceding $10 \mathrm{yr}$ (NOAA Fisheries 2019). The most recent stock assessment of haddock in the GOM states that a better understanding of recruitment processes is necessary to improve future forecasting of the stock (NEFSC 2017). Because haddock and redfish are eaten by puffins on these colonies at age 0 , data from puffin diet could help us better understand the processes influencing age-1 recruitment by providing information about juvenile fish before they are sampled by fishery-independent surveys. For example, while age-0 haddock lengths measured during the fall are not a good predictor of recruitment (Friedland et al. 2008), lengths measured earlier in the year may predict recruitment because haddock that hatch earlier and are larger when they hatch are more likely to survive to the fall (Lapolla \& Buckley 2005).

Although useful, there are challenges in using seabird diet to make inferences about fish populations. First, proportions of fish biomass in diet may not reflect relative abundances. Even 'generalist' seabirds may alter their foraging strategy to target specific prey items (Elliott et al. 2008b). For example, rhinoceros auklets Cerorhinca monocerata forage at particular locations and depths for particular prey items, although there appears to be little individual dietary specialization (Cunningham et al. 2018). Predators should take into account both relative abundance and energy content and select the most energetically profitable prey (Emlen 1966). As such, we are more likely to observe relationships between puffin diet and the abundances of more preferable prey species. Based on relationships between diet and reproductive parameters, the most valuable prey item to puffin chicks in the GOM is redfish (Scopel et al. 2019), which have a high energy density (Budge et al. 2002); however, white hake and haddock appear to be as valuable as herring and sand lance (Scopel et al. 2019), despite the higher energy densities of the latter (Budge et al. 2002). Puffins are less dependent on high-energy prey than other alcids such as razorbills Alca torda and common murres Uria aalge due to their lower flight cost, larger prey load size, and 
longer chick-rearing season (Burke \& Montevecchi 2008, Scopel et al. 2019). Second, the abundances of prey species within the foraging range of puffins may not be representative of abundances over the entire GOM. To account for the larger geographic scale of a fish stock compared to a seabird colony, principal component analysis (PCA) can be used to integrate observations from multiple colonies into single variables for each fish species, which represent largescale patterns common to all colonies (e.g. juvenile rockfish in the California Current, Mills et al. 2007; forage fish in the North Pacific, Sydeman et al. 2017).

The focus of this study was to investigate relationships between puffin diet composition and the abundance of haddock and redfish in the GOM, including spatial differences in the amount of age-0 haddock and redfish eaten by puffins in each colony. We tested if SSB is a predictor of the amount of haddock and redfish eaten by puffins and if the amount of haddock and redfish eaten by puffins is a predictor of the number of age-1 recruits of haddock and redfish the following year. We also investigated spatial differences in the lengths of haddock observed in puffin diet in each colony and tested if haddock length is a predictor of the number of age-1 recruits of haddock the following year.

\section{MATERIALS AND METHODS}

\subsection{Study site}

Long-term diet studies have been conducted at Atlantic puffin colonies on 4 islands in the GOM: Eastern Egg Rock, Matinicus Rock, and Seal Island National Wildlife Refuge (NWR), located off mid-coast Maine, and Machias Seal Island, located between the GOM and Bay of Fundy (Fig. 1). Eastern Egg Rock is located in Muscongus Bay $9 \mathrm{~km}$ from the mainland, Matinicus Rock and Seal Island NWR are located in Penobscot Bay 32 $\mathrm{km}$ from the mainland and $14 \mathrm{~km}$ from each other, and Machias Seal Island is located between the GOM and Bay of Fundy, $16 \mathrm{~km}$ from the mainland and $19 \mathrm{~km}$ from Grand Manan Island. Eastern Egg Rock, Matinicus Rock, and Seal Island NWR are managed by the National Audubon Society Seabird Restoration Program (SRP), while Machias Seal Island is managed by the Canadian Wildlife Service and monitored by the University of New Brunswick. Foraging distance and for- aging depth have not been determined for puffins at the 3 SRP colonies, but on Machias Seal Island and the nearby Petit Manan Island, puffins forage at average distances of 38 and $31 \mathrm{~km}$, respectively, and at average depths of 17 and $10 \mathrm{~m}$, though depths of up to $41 \mathrm{~m}$ have been recorded (Spencer 2012, Symons 2018).

Major prey items on all 4 colonies include Atlantic herring Clupea harengus, white hake Urophycis tenuis and fourbeard rockling Enchelyopus cimbrius (not distinguishable from white hake in the field), sand lance (Ammodytes sp.), haddock Melanogrammus aeglefinus, and American butterfish Peprilus triacanthus. Acadian redfish Sebastes fasciatus appear sporadically in puffin diet on the 3 mid-coast colonies only. Recent changes in puffin diet have been observed at all 4 colonies, including a decline in Atlantic herring and increases in formerly rare species (Kress et al. 2016, Scopel et al. 2018). Haddock and redfish were not observed in puffin diet until 2010 and 2011, respectively.

Both haddock and redfish are presumably exclusively eaten by puffins at our study sites at age 0 . While the otoliths of fish in puffin diet were not examined for aging, the lengths of haddock and redfish observed in puffin diet are comparable to expected lengths of age-0 haddock and redfish from

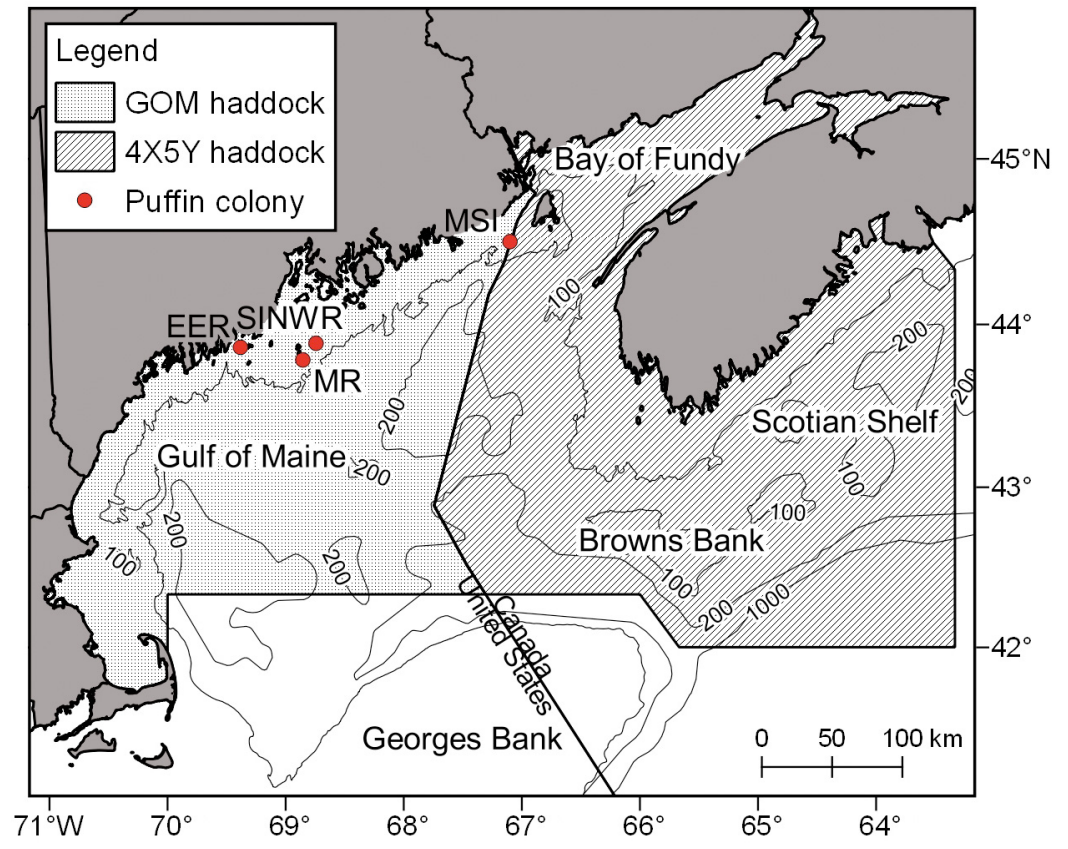

Fig. 1. Locations of the 4 Atlantic puffin colonies in this study (EER: Eastern Egg Rock; MR: Matinicus Rock; SINWR: Seal Island National Wildlife Refuge; and MSI: Machias Seal Island) and the boundaries of the US-managed Gulf of Maine (GOM) and Canada-managed 4X5Y haddock stocks. Adapted from Roworth \& Signell (1998), NAFO (2015), and Flanders Marine Institute (2018) 
the literature (Kelly \& Barker 1961, Penney \& Evans 1985, Bolz \& Lough 1988, Lapolla \& Buckley 2005, NEFSC 2014). Haddock is fast-growing and oviparous with a high reproductive rate, while redfish is slow-growing and ovoviviparous with a lower reproductive rate (Miller et al. 2008, NEFSC 2014). Peak spawning for haddock in the GOM occurs in March (Lapolla \& Buckley 2005). Larval release of redfish in the GOM peaks in late May to early June (Morse et al. 1987, Mayo et al. 1990). Pelagic larvae and juveniles of both species are transported by currents in a counterclockwise direction around the GOM (Sherman et al. 1984). Haddock settle to the bottom at lengths of 6-10 cm during late summer (Miller et al. 1963, Auditore et al. 1994, Lapolla \& Buckley 2005), primarily onto pebble gravel deposits (Lough et al. 1989), and redfish settle to the bottom at lengths of 4-5 cm during early autumn (Kelly \& Barker 1961), primarily onto boulder reefs (Auster et al. 2003). Haddock and redfish targeted by puffins are likely at the transition between pelagic and demersal juvenile life stages (Kelly \& Barker 1961, Anderson 1994, Auditore et al. 1994).

Haddock and redfish are harvested as part of multispecies groundfish fisheries in both US and Canadian waters. Haddock and redfish around the 3 midcoast colonies belong to the US-managed GOM haddock stock and the Gulf of Maine-Georges Bank Acadian redfish stock, respectively. Haddock around Machias Seal Island could belong to the US-managed GOM haddock stock or the Canada-managed 4X5Y haddock stock, which includes the Bay of Fundy and western Scotian Shelf (Begg 1998) (Fig. 1). Stocks are assessed based on a combination of fishery-dependent and fishery-independent data, including commercial and recreational catch-at-age and stratified-random bottom trawl surveys conducted during the spring and fall in the GOM (Politis et al. 2014, NEFSC 2017) and during the summer in the Bay of Fundy and Scotian Shelf region (Finley et al. 2018).

\subsection{Data collection}

Atlantic puffin chick diet, including the species and length (estimated relative to adult bill length) of each prey item, was observed from 2005 to 2017 on Eastern Egg Rock, Matinicus Rock, and Seal Island NWR and from 1995 to 2017 on Machias Seal Island. Observation methods varied by program and over time; detailed methods were reported by Kress et al. (2016) and Scopel et al. (2018). In summary, prey deliveries were observed using binoculars or cameras from multiple observation blinds on each colony. Blinds were located such that at least 10 burrows were viewable within $\sim 15 \mathrm{~m}$. Observations were conducted in 2-3 $\mathrm{h}$ stints at different times of the day from peak hatch ( mid-June) to early August, for an average of (mean \pm SE) $\sim 112 \pm 11 \mathrm{~h} \mathrm{colony}^{-1} \mathrm{yr}^{-1}$. From 2005 to 2017, we observed an average of $($ mean $\pm \mathrm{SE}) \sim 390 \pm 42$ prey deliveries colony ${ }^{-1} \mathrm{yr}^{-1}$. Voucher specimens were collected opportunistically to verify fish identification. While redfish (Sebastes spp.) cannot be identified to the species level during field observations, Acadian redfish is the only redfish species found in the GOM (Sévigny et al. 2007), and the 2 collected specimens of redfish were Acadian redfish. Due to insufficient view, $13 \%$ of prey deliveries were not identified and were therefore excluded from the analysis.

Annual estimates of SSB and age-1 recruits for each fish stock, calculated using a statistical catchat-age model (Acadian redfish and GOM haddock; Legault \& Restrepo 1998, Miller et al. 2008, NEFSC 2014) or virtual population analysis (4X5Y haddock; Finley et al. 2018), were taken from the NOAA Species Information System Public Portal (Acadian redfish and GOM haddock; NOAA Fisheries 2019) and from the 2016 4X5Y haddock stock assessment (Finley et al. 2018). At the time of the analysis, SSB and age-1 recruits had been updated to 2016 for the 3 groundfish stocks. Projections of SSB from the most recent stock assessments were used for 2017 (NEFSC 2017, Finley et al. 2018).

\subsection{Data preparation}

Data preparation and statistical analyses were performed using R v.3.5.3 (R Core Team 2019). For each colony and year, we calculated 2 measures of haddock in puffin diet, i.e. proportion of diet by mass and mean length, and 1 measure of redfish in puffin diet, i.e. proportion of diet by mass. We did not compare redfish lengths across colonies or years because redfish were not observed during the same years on all colonies. Proportions of diet by mass were calculated following the procedure outlined by Scopel et al. (2018) (Fig. 2). In summary, for each colony, prey items that made up less than $1 \%$ of diet by number were excluded from the analysis, and the remainder of prey deliveries were converted into wet mass. Length-mass conversion formulae were developed from prey samples collected at Machias Seal Island when possible and otherwise taken from the litera- 


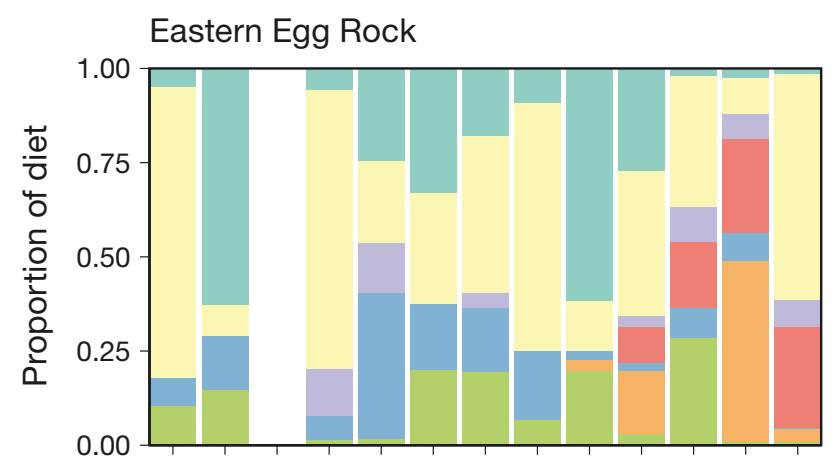

\section{Matinicus Rock}

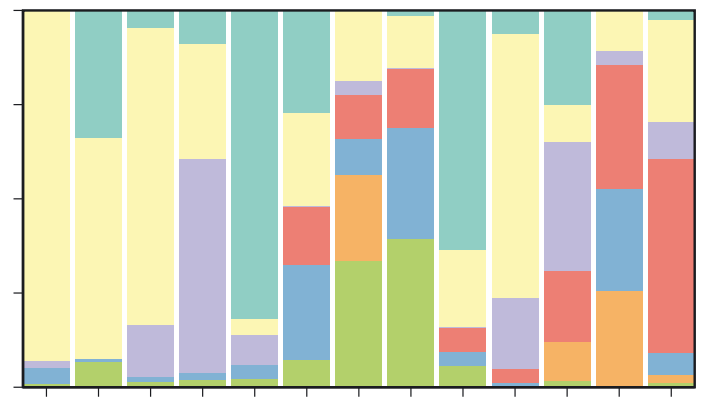

Machias Seal Island

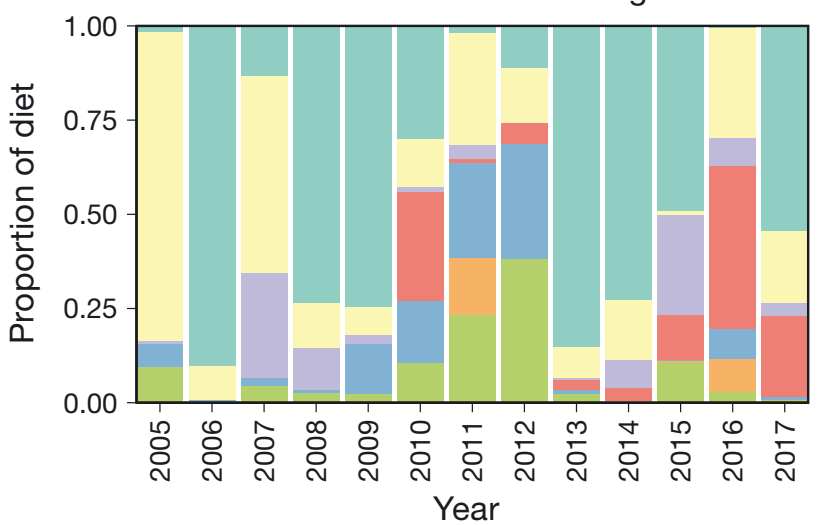

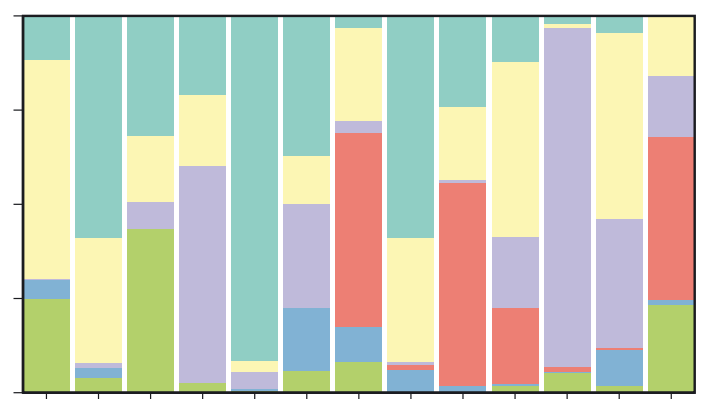

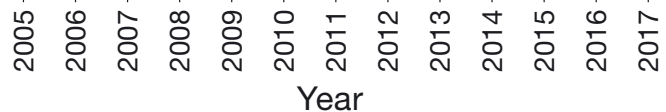

Year

Prey item Atlantic herring
White hake/fourbeard rockling

Sand lance

A American butterfish Other Haddock Acadian redfish

Fig. 2. Atlantic puffin chick diet composition on Eastern Egg Rock, Matinicus Rock, Seal Island National Wildlife Refuge, and Machias Seal Island from 2005 to 2017. Proportions in diet were calculated by mass. 'Other' includes unidentified larval fish, Atlantic saury, Atlantic mackerel, bluefish, euphausiids, pollock, squid, and rough scad. Diet on Eastern Egg Rock in 2007 is not shown due to small sample size

ture. The conversion formulae used for each prey item are reported by Scopel et al. (2018).

In addition to developing measures of haddock and redfish use by puffins at individual colonies, we used PCA to represent the proportions of haddock and redfish in puffin diet across all colonies as a single variable for each fish species. PCA reduces the number of variables necessary to describe multivariate data by transforming a set of possibly correlated variables - in this case, proportions of a fish species in puffin diet on multiple colonies - into a set of uncorrelated variables called principal components (PCs). Each PC has the highest variance possible under the constraint that it is uncorrelated with preceding PCs, allowing multivariate data to be summarized by just a few PCs. The contributions of each variable to each $\mathrm{PC}$ are described by loadings. The sign of a loading indicates whether the correlation is positive or negative. PCA was performed using the factoextra R pack- age (Kassambara \& Mundt 2017). The Hellinger transformation (square root of proportions) was applied prior to performing PCA to reduce the horseshoe effect, which is a common distortion that occurs when PCA is used on community composition data (Legendre \& Gallagher 2001). For haddock, we performed PCA both including and excluding Machias Seal Island, because while haddock proportions on the SRP colonies are likely only influenced by the GOM haddock stock, haddock proportions on Machias Seal Island could be influenced by the GOM haddock stock or the 4X5Y haddock stock (Begg 1998).

In all cases, PC1 represented temporal variation in use of the prey item common to all colonies (i.e. the loadings of each colony on each PC1 were similar), while PC2 represented spatial variation among colonies (i.e. the loadings of each colony on each PC2 corresponded to the geographic locations of the colonies; 
Machias Seal Island loaded opposite of the SRP colonies, and when Machias Seal Island was excluded, Eastern Egg Rock loaded opposite of Matinicus Rock and Seal Island NWR; Fig. 3). PC1 explained $61 \%$ of the variation in haddock use across all 4 colonies, $85 \%$ of the variation in haddock use across the 3 SRP colonies, and $71 \%$ of the variation in redfish use across the 3 SRP colonies (Table 1). We retained the scores of each year on each PC1 for further analysis against fisheries variables. PC2s were not retained for comparison to stock-wide fisheries variables because they did not represent trends in puffin diet common to all colonies.

\subsection{Statistical analyses}

ANOVA and Tukey's HSD test were used to determine the effects of colony and year on haddock lengths in puffin diet. The assumptions of normality and homogeneity of variances were verified using normal Q-Q plots and residuals vs. fitted plots. Type III sums of squares (using estimated marginal means) were used to account for the unbalanced design. Type III ANOVA and pairwise comparisons of estimated marginal means were performed using the $\mathrm{R}$ packages 'car' (Fox \& Weisberg 2011) and 'emmeans' (Lenth et al. 2019).

Simple linear regression was used to test for relationships between measures of haddock and redfish in puffin diet (proportions of each prey item on each colony, PC1s of proportions of each prey item across all colonies, and mean lengths of haddock on each colony) and fishery- and survey-derived estimates of SSB (the same year) and age-1 recruits (the following year) for each stock (Table 2). By testing only linear relationships, we looked for puffin diet-derived indices of juvenile fish abundance that show magnitudes of change comparable to those of the fish stocks. We assumed that there is no density-dependent prey switching; however, true relationships may be more complicated. To restrict comparisons to compatible time series, data from Machias Seal Island prior to 2005 were excluded. All variables were standardized (mean $=0 ; \mathrm{SD}=1$ ) prior to regression analysis. The mean length of haddock on Eastern Egg Rock was not used in regression analysis due to small sample size. Non-significant $(p \geq 0.05)$ models were rejected, while significant models $(p<0.05)$ were retained for further investigation.

To increase model reliability, Allen's predicted residual error sum-of-squares (PRESS) statistic (Allen 1971) was used to assess the predictive power of sig-
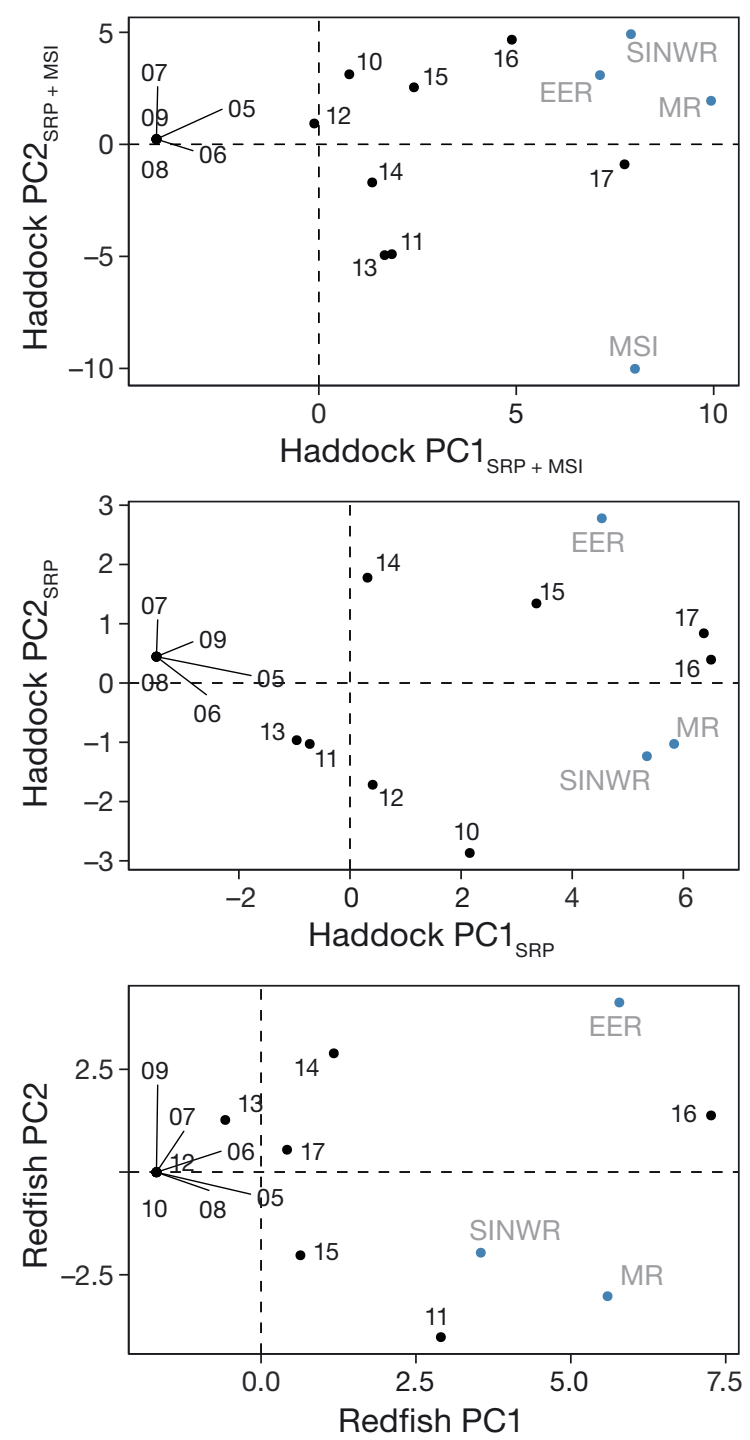

Fig. 3. PCA biplots generated from haddock and Acadian redfish proportions in Atlantic puffin chick diet on EER, MR, SINWR, and MSI (see Fig. 1) between 2005 and 2017. PCA was performed separately for each fish species. For haddock, PCA was performed both including and excluding MSI (denoted PC1 $1_{\mathrm{SRP}+\mathrm{MSI}}$ and $\mathrm{PC} 1_{\mathrm{SRP}}$ ). Redfish were not observed on MSI. In all cases, PC1 represents temporal variation in use of the prey item common to all colonies (i.e. the loadings of each colony on each PC1 are similar), while PC2 represents spatial variation among colonies (i.e. the loadings of each colony on each PC2 correspond to the geographic locations of the colonies). The scores of each year on each PC1 were retained for further analysis against fisheries variables

nificant models. Allen's PRESS statistic is a form of leave-one-out cross-validation defined as the sum of squared differences between each observation and the predicted values of those observations when those observations are removed from the data set. From the PRESS statistic, we calculated the predic- 
Table 1. PCA results for haddock and Acadian redfish proportions in Atlantic puffin diet across 4 colonies (see Fig. 1) between 2005 and 2017, showing the proportion of variation in use of each species explained by PC1 and PC2 and the loadings of each colony on each principal component. For haddock, PCA was performed both including and excluding MSI. Redfish were not observed on MSI

\begin{tabular}{|lcccccc|}
\hline \multirow{2}{*}{ Prey item } & \multirow{2}{*}{ PC } & Prop. & \multicolumn{4}{c|}{ Loadings } \\
\cline { 5 - 7 } & & variance & EER & MR & SINWR & MSI \\
\hline Haddock & 1 & 0.613 & 1.67 & 2.33 & 1.86 & 1.88 \\
(all colonies) & 2 & 0.306 & 0.726 & 0.457 & 1.16 & -2.35 \\
Haddock & 1 & 0.852 & 1.82 & 2.34 & 2.15 & \\
(SRP colonies) & 2 & 0.106 & 1.12 & -0.413 & -0.496 & \\
Redfish & 1 & 0.705 & 1.73 & 1.68 & 1.06 & \\
& 2 & 0.274 & 1.24 & -0.906 & -0.589 & \\
& & & & & & \\
\end{tabular}

tive squared correlation coefficient $\left(\mathrm{Q}^{2}\right)$ to allow for comparison between models of differing sample size. $\mathrm{Q}^{2}$ is an analog to the coefficient of determination $\left(\mathrm{R}^{2}\right)$ and is defined as one minus the ratio of the PRESS statistic to the sum of squared differences between each observation and the mean of all other observations (Quan 1988). $Q^{2}$ approaches $R^{2}$ when the model is highly predictive and takes negative values when the model is less predictive than the mean.

\section{RESULTS}

\subsection{Differences in diet among colonies}

The PC2s of both haddock and redfish PCAs separated Machias Seal Island from the SRP colonies and Eastern Egg Rock from Matinicus Rock and Seal Island NWR (Fig. 3), suggesting that proportions in diet were influenced by annual differences in the geographic distributions of juvenile haddock and redfish. Both haddock and redfish appeared on Matinicus Rock and Seal Island NWR several years before appearing on Eastern Egg Rock. In 2011 and 2013, haddock predominated diet on Machias Seal Island but only appeared in small numbers on the SRP colonies, while in 2016, haddock made up about a third of diet on the SRP colonies but $<1 \%$ of diet on Machias Seal Island. Redfish were also abundant on different colonies during different years (Fig. 2).

\subsection{Effects of colony and year on haddock length}

Haddock lengths varied significantly among colonies $\left(F_{3,3386}=326.82, \mathrm{p}<0.001\right)$ and among years $\left(F_{7,3386}=114.53, \mathrm{p}<0.001\right)$, with haddock on Machias Seal Island significantly larger than haddock on the 3

Table 2. Summary of relationships tested between Atlantic puffin diet variables and fisheries variables for haddock and Acadian redfish. Puffin diet variables included proportions of each prey item on individual colonies (abbreviations as in Fig. 1), PCA-derived measures (PC1) of proportions of each prey item across all colonies, and mean lengths of haddock on individual colonies. Fisheries variables included estimates of spawning stock biomass (SSB; the same year) and age-1 recruits (the following year) for each stock (US-managed Gulf of Maine (GOM) haddock, Canada-managed 4X5Y haddock, and US-managed Gulf of Maine-Georges Bank (GOM-GB) Acadian redfish). Diet-fishery variable pairs colored green had significant ( $p<0.05$ ) positive relationships and passed cross-validation (Table 3). Pairs colored yellow had significant positive relationships but failed cross validation (predictive squared correlation coefficient $Q^{2} \leq \sim 0$ ), pairs colored red did not have significant relationships, and uncolored pairs were not tested

\begin{tabular}{|c|c|c|c|c|c|c|c|}
\hline & \multirow[t]{3}{*}{ Colony } & \multicolumn{4}{|c|}{ Haddock } & \multirow{2}{*}{\multicolumn{2}{|c|}{$\begin{array}{l}\text { Redfish } \\
\text { GOM-GB }\end{array}$}} \\
\hline & & 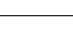 & $\mathrm{OM}$ & 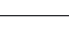 & $4 \mathrm{X} 5 \mathrm{Y}$ & & \\
\hline & & SSB & Age-1 recruits & SSB & Age- 1 recruits & SSB & Age-1 recruits \\
\hline \multicolumn{8}{|l|}{ Haddock } \\
\hline \multirow[t]{6}{*}{ Proportion } & EER & & & & & & \\
\hline & MR & & & & & & \\
\hline & SINWR & & & & & & \\
\hline & MSI & & & & & & \\
\hline & $P C 1_{S R P}+$ MSI & & & & & & \\
\hline & $P C 1_{\mathrm{SRP}}$ & & & & & & \\
\hline \multirow[t]{3}{*}{ Length } & $\mathrm{MR}$ & & & & & & \\
\hline & SINWR & & & & & & \\
\hline & MSI & & & & & & \\
\hline \multicolumn{8}{|l|}{ Redfish } \\
\hline \multirow[t]{4}{*}{ Proportion } & EER & & & & & & \\
\hline & MR & & & & & & \\
\hline & SINWR & & & & & & \\
\hline & PC1 & & & & & & \\
\hline
\end{tabular}


SRP colonies $(\mathrm{p}<0.001)$. On average, haddock on Machias Seal Island measured $8.5 \pm 0.058 \mathrm{~cm}$ (mean $\pm \mathrm{SE}$ ), while haddock on Eastern Egg Rock, Matinicus Rock, and Seal Island NWR measured $5.6 \pm 0.15$, $5.3 \pm 0.065$, and $5.3 \pm 0.070 \mathrm{~cm}$, respectively. Haddock were observed slightly later in the season on Machias Seal Island than on the SRP colonies, with mean observation dates of 26 July \pm 10 d (SD), 20 July $\pm 10 \mathrm{~d}, 17$ July $\pm 10 \mathrm{~d}$, and 14 July $\pm 11 \mathrm{~d}$ for Machias Seal Island, Eastern Egg Rock, Matinicus Rock, and Seal Island NWR, respectively; however, there was no consistent relationship between observation date and length within groups. Haddock were largest in 2013, measuring $9.5 \pm 0.12 \mathrm{~cm}$ on average, and smallest in 2012, measuring on average $4.6 \pm$ $0.10 \mathrm{~cm}$.

\subsection{Relationships between diet variables and fisheries variables}

Of the 30 relationships tested, 11 were significant at $\alpha=0.05$ (Table 2), but 5 significant relationships failed cross-validation $\left(\mathrm{Q}^{2} \leq \sim 0\right.$; Table 3$)$. GOM haddock SSB was a strong predictor of haddock proportion on Eastern Egg Rock $\left(\mathrm{p}<0.001, \mathrm{R}^{2}=0.92, \mathrm{Q}^{2}=\right.$ $0.82)$, haddock proportion on Matinicus Rock ( $\mathrm{p}<$ $\left.0.001, \mathrm{R}^{2}=0.81, \mathrm{Q}^{2}=0.78\right)$, and both PCA-derived measures of haddock proportions (all colonies: $\mathrm{p}=$ 0.0016, $\mathrm{R}^{2}=0.61, \mathrm{Q}^{2}=0.59$; SRP colonies: $\mathrm{p}<0.001$, $\mathrm{R}^{2}=0.68, \mathrm{Q}^{2}=0.58$ ); redfish SSB was a moderate predictor of the PCA-derived measure of redfish proportions $\left(\mathrm{p}=0.0080, \mathrm{R}^{2}=0.49, \mathrm{Q}^{2}=0.31\right)$; and haddock length on Machias Seal Island was a moderate predictor of age-1 recruitment for the $4 \mathrm{X} 5 \mathrm{Y}$ haddock stock ( $p=0.033, R^{2}=0.82, Q^{2}=0.44$; Fig. 4). Proportions of haddock and redfish in puffin diet did not predict age-1 recruitment.

\section{DISCUSSION}

We found multiple relationships between measures of haddock and redfish in puffin diet and fishery- and survey-derived estimates of haddock and redfish abundance. Differences in puffin diet composition among colonies were not consistent year to year and appear to be influenced by annual differences in the geographic distributions of juvenile fish targeted by puffins. While a fish stock covers a much wider geographic area than a seabird colony, we have shown that PCA can be used to integrate observations from multiple colonies to capture large-scale patterns. In the case of redfish, the PCA-derived measure of proportions across the 3 SRP colonies was a better indicator of SSB than proportions on any individual colony. This result corroborates similar findings by Mills et al. (2007), who created multivariate indices of juvenile rockfish abundance in the California Current by using PCA to combine data from seabird diet, salmon stomach contents, and midwater trawl surveys, and by Sydeman et al. (2017), who found relationships between environmental variables and PCA-derived indicators of sand lance, capelin, and gadids in the diets of 3 seabirds at multiple sites in the North Pacific.

Table 3. Sample sizes (n), slopes (m), coefficients of determination $\left(\mathrm{R}^{2}\right)$, p-values, and predictive squared correlation coefficients $\left(Q^{2}\right)$ for significant $(p<0.05)$ relationships between Atlantic puffin diet variables and fisheries variables for haddock and Acadian redfish. Puffin diet variables included proportions of each prey item on individual colonies (abbreviations as in Fig. 1), PCA-derived measures (PC1) of proportions of each prey item across all colonies, and mean lengths of haddock on individual colonies. Fisheries variables included estimates of spawning stock biomass (SSB; the same year) and age-1 recruits (the following year) for each stock (abbreviations as in Table 2). All variables were standardized (mean $=0 ; \mathrm{SD}=1$ ) prior to regression analysis. Five relationships failed cross-validation $\left(Q^{2} \leq \sim 0\right)$

\begin{tabular}{|c|c|c|c|c|c|c|}
\hline Puffin diet variable & Fisheries variable & $\mathrm{n}$ & $\mathrm{m}$ & $\mathrm{R}^{2}$ & $\mathrm{p}$ & $\mathrm{Q}^{2}$ \\
\hline Haddock proportion: EER & GOM haddock SSB & 13 & 0.96 & 0.92 & $<0.001$ & 0.82 \\
\hline Haddock proportion: MR & GOM haddock SSB & 13 & 0.90 & 0.81 & $<0.001$ & 0.78 \\
\hline Haddock proportion: $\mathrm{PC} 1_{\mathrm{SRP}+\mathrm{MSI}}$ & GOM haddock SSB & 13 & 0.78 & 0.61 & 0.0016 & 0.59 \\
\hline Haddock proportion: $\mathrm{PC} 1_{\mathrm{SRP}}$ & GOM haddock SSB & 13 & 0.83 & 0.68 & $<0.001$ & 0.58 \\
\hline Haddock length: MSI & 4X5Y haddock age-1 recruits following year & 5 & 0.91 & 0.82 & 0.033 & 0.44 \\
\hline Redfish proportion: PC1 & Redfish SSB & 13 & 0.70 & 0.49 & 0.0080 & 0.31 \\
\hline Redfish proportion: EER & Redfish SSB & 13 & 0.59 & 0.35 & 0.034 & 0.012 \\
\hline Haddock proportion: SINWR & GOM haddock SSB & 13 & 0.65 & 0.42 & 0.017 & 0.0014 \\
\hline Haddock proportion: MSI & 4X5Y haddock age-1 recruits following year & 11 & 0.71 & 0.51 & 0.014 & -0.40 \\
\hline Haddock proportion: MSI & GOM haddock age-1 recruits following year & 11 & 0.63 & 0.40 & 0.038 & -0.57 \\
\hline Haddock length: MR & GOM haddock age-1 recruits following year & 6 & 0.84 & 0.70 & 0.038 & -1.0 \\
\hline
\end{tabular}



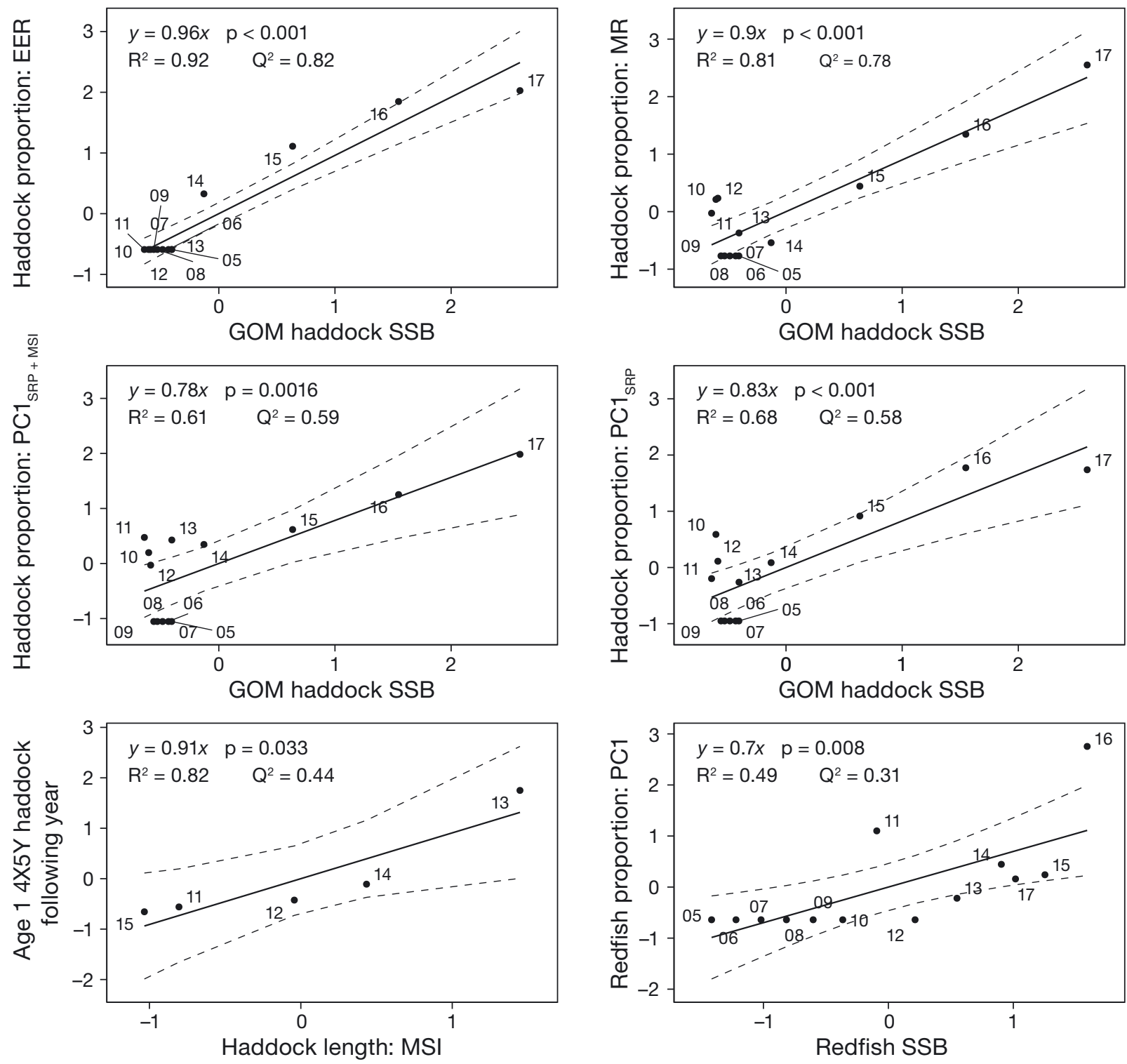

Fig. 4. Relationships between Atlantic puffin diet variables and fisheries variables for haddock and Acadian redfish that passed cross-validation, with 95\% confidence intervals. Puffin diet variables included proportions of each prey item on individual colonies (abbreviations as in Fig. 1), PCA-derived measures (PC1) of proportions of each prey item across all colonies, and mean lengths of haddock on individual colonies. Fisheries variables included estimates of spawning stock biomass (SSB; the same year) and age- 1 recruits (the following year) for each stock (abbreviations as in Table 2 ). All variables were standardized (mean $=0$; $\mathrm{SD}=1$ ) prior to regression analysis

While PCA-derived measures of haddock and redfish in puffin diet were strong indicators of stock-wide SSB, spatial differences ignored by the PCA approach are also important. In the case of haddock, individualcolony proportions on 2 of the 4 colonies were better indicators of SSB than the 2 PCA-derived measures. While fisheries are generally assessed and managed at the stock level, many stocks have complex substock structures with multiple spawning components. Failure to account for sub-stock structure in manage- ment strategies can result in the collapse of spawning components, leading to local depletions and loss of genetic diversity (Stephenson 1999). Prior to the collapse and recent recovery of the GOM haddock stock, the stock was composed of multiple spawning components with discrete spawning grounds along the Maine coast (Ames 1997). Little is known about the spawning locations of GOM haddock today (NEFSC 2014), but differences in juvenile haddock abundance and length around the 4 colonies may indicate stock 
complexity that should be further investigated. Redfish in the GOM are thought to be a single population based on genetic information, but highly variable morphology within the region also warrants further investigation (Valentin et al. 2014).

Observations of seabird diet may provide insight into the stock structures and early life histories of prey species. The GOM haddock stock spawns along the inshore GOM from March to April, while the 4X5Y haddock stock spawns on Browns Bank from April to May (Page \& Frank 1989); however, haddock in the Bay of Fundy may be a mixture of both stocks (Begg 1998). A fraction of larvae from the 4X5Y stock drift north to settle on nursery grounds in the inshore region off Yarmouth, Nova Scotia, just south of the Bay of Fundy (Brickman 2003). Haddock on Machias Seal Island were $3.1 \mathrm{~cm}$ larger and were observed 8 $\mathrm{d}$ later on average than haddock on the SRP colonies. The mean growth rate of age- 0 GOM haddock (0.066 $\mathrm{cm} \mathrm{d}^{-1}$; Lapolla \& Buckley 2005) does not account for the observed size difference, suggesting that haddock on Machias Seal Island represent a different stock or sub-stock. While the $4 \mathrm{X} 5 \mathrm{Y}$ stock spawns later than the GOM stock, juvenile haddock in this region could belong to the $4 \mathrm{X} 5 \mathrm{Y}$ stock if they represent an earlier-spawning component of the stock or if growth rates in the region are high enough to overcome the later spawning date. Stronger currents from Browns Bank into the Bay of Fundy during the earlier portion of the spawning season may result in increased larval drift into the Bay of Fundy in years that haddock spawn earlier (Brickman et al. 2001). Juvenile 4X5Y haddock in the inshore region off Yarmouth, Nova Scotia grow faster than juveniles on Browns Bank (Brickman 2003), but juvenile growth rates in this region have not been compared to juvenile growth rates along the coast of Maine.

It is important to note that there is potential for observer bias when comparing fish lengths, especially between Machias Seal Island and the SRP colonies, which are monitored by different organizations. A study on prey identification in terns on the SRP colonies found that in paired trials between experienced and inexperienced observers, $68 \%$ of estimates were within 0.25 bill lengths $(0.74 \mathrm{~cm})$ (Hall 1999). Another study found that prey lengths could be accurately estimated in thick-billed murres Uria lomvia, although lengths were systematically underestimated by $\sim 1 \mathrm{~cm}$ (Elliott et al. 2008a). Similarly, visual observations of the length of prey brought back by razorbills (as estimated by multiple of bill length) averaged $20 \%$ less than verified measurements from photographs or dropped fish (Lavoie et al. 2012). Future research should investigate the stock origin of haddock on Machias Seal Island using physiological or genetic information.

Proportions in puffin diet did not predict age-1 recruitment in haddock or redfish, but haddock length on Machias Seal Island was a moderate predictor of age-1 recruitment for the 4 X5Y stock, despite a small sample size of years $(n=5)$. Haddock recruitment in the GOM and Bay of Fundy region is poorly understood. In the neighboring Georges Bank stock, the timing and magnitude of the autumn phytoplankton bloom has a strong impact on recruitment the following year through maternal provisioning; that is, larger, earlier-autumn phytoplankton blooms result in better maternal condition, which results in larger, better-conditioned offspring (Friedland et al. 2008, Leaf \& Friedland 2014) that are more likely to survive predation pressure at the juvenile stage during the summer (Lapolla \& Buckley 2005); however, the autumn phytoplankton bloom does not predict recruitment in the GOM (Friedland et al. 2015). Earlier spring phytoplankton blooms result in better larval feeding conditions and higher recruitment on the eastern Scotian Shelf (4VTW stock) but not on the western Scotian Shelf (Trzcinski et al. 2013). Redfish recruitment in the GOM is influenced by the North Atlantic Oscillation index 2 yr prior, water temperature, and windstress, which seem to affect early life history stage survival (Brodziak \& O'Brien 2005), but high variability in age-0 mortality during the autumn could obscure any relationship between the number of juvenile fish available to puffins during the summer and the number of age-1 recruits during the winter. Future research should investigate the potential of redfish length as a predictor of recruitment.

While the proportions of haddock and redfish in puffin diet in recent years seem to reflect trends in $\mathrm{SSB}$, it is unclear why haddock and redfish did not appear in puffin diet prior to 2010. The 1998 and 2003 year classes of haddock and the 2007 year class of redfish were comparable to or larger than more recent year classes. A possible explanation is that haddock and redfish recovered elsewhere in the GOM before appearing around the puffin colonies. Haddock first recovered in the western GOM and only recently began to repopulate the eastern GOM (NEFSC 2014). Alternatively, puffins may have switched to haddock and redfish following decreased availability of white hake and Atlantic herring, important prey species that are sensitive to warming temperatures (Rose 2005, Kleisner et al. 2017). Concerningly, both haddock and redfish are projected to experience losses of suitable thermal 
habitat in the GOM due to climate change (Kleisner et al. 2017). Such changes in thermal habitat may also allow predatory fish to reduce prey populations or outcompete pursuit-diving birds (Cairns et al. 2008), altering puffin diet. Continued monitoring of puffin diet will not only be important to ensure the health of puffin colonies at the southern limit of their range, but also may provide an early warning about temperature-related changes in prey distributions, phenologies, and growth rates (Frederiksen et al. 2011).

Puffin diet was a good hindcast indicator of haddock and redfish abundance (i.e. SSB-predicted puffin diet), but a weak forecast indicator (i.e. puffin diet was not a strong predictor of recruitment). The processes influencing recruitment in fish stocks are poorly understood, and there is often little relationship between SSB and recruitment (Szuwalski et al. 2015). Sampling of juvenile fish by seabirds may provide information about cohort size during this poorly understood period. Strong predictive relationships between SSB and the proportions of juvenile haddock and redfish in puffin diet - but not between proportions in puffin diet and age-1 recruitment - suggest that variation in age- 1 recruitment is caused by processes affecting juvenile survival after the puffin breeding season rather than processes affecting larval survival or the number of eggs produced. Puffin diet provided more information about haddock than about redfish due to the larger sample size and range of occurrence of haddock, but future research should further investigate the potential of length as a predictor of recruitment in both species. Even if puffin diet cannot predict stock-wide recruitment, it could be used in a population model as an index of age-0 abundance (Field et al. 2007). Furthermore, the spatial differences observed in puffin diet may provide useful information about stock structure. The differing dynamics and larger size of juvenile haddock observed on Machias Seal Island compared to the SRP colonies suggest that juvenile haddock on the boundary of the GOM and Bay of Fundy originate from a different stock or sub-stock than juvenile haddock off mid-coast Maine. The stock structure of haddock in this region should be further investigated.

Acknowledgements. We thank the research assistants and staff of the National Audubon Society Seabird Restoration Program and the University of New Brunswick Atlantic Laboratory for Avian Research for their care in collecting the seabird diet data summarized here. We thank Scott Hall for his role in initiating diet studies on the colonies managed by the National Audubon Society. We also thank Don Lyons, Anna Weinstein, and 2 anonymous reviewers for their help- ful comments on an earlier draft of this manuscript. We acknowledge support for this study from the National Audubon Society Seabird Restoration Program, the Canadian Wildlife Service, Environment and Climate Change Canada, the New Brunswick Wildlife Trust Fund, the Natural Sciences and Engineering Research Council of Canada, and the University of New Brunswick.

\section{LITERATURE CITED}

Allen DM (1971) Mean square error of prediction as a criterion for selecting variables. Technometrics 13:469-475

Ames EP (1997) Cod and haddock spawning grounds of the Gulf of Maine from Grand Manan to Ipswich Bay. In: Hunt von Heerbing I, Kornfield I, Tupper M, Wilson J (eds) The implications of localized fishery stocks. Natural Resource, Agriculture, and Engineering Service, Ithaca, NY, p 55-64

Anderson JT (1994) Feeding ecology and condition of larval and pelagic juvenile redfish Sebastes spp. Mar Ecol Prog Ser 104:211-226

Auditore PJ, Lough RG, Broughton EA (1994) A review of the comparative development of Atlantic cod (Gadus morhua L.) and haddock (Melanogrammus aeglefinus L.) based on an illustrated series of larvae and juveniles from Georges Bank. Northwest Atl Fish Organ Sci Counc Stud 20:7-18

Auster PJ, Lindholm J, Valentine PC (2003) Variation in habitat use by juvenile Acadian redfish, Sebastes fasciatus. Environ Biol Fishes 68:381-389

Barrett RT (2002) Atlantic puffin Fratercula arctica and common guillemot Uria aalge chick diet and growth as indicators of fish stocks in the Barents Sea. Mar Ecol Prog Ser 230:275-287

Begg GA (1998) A review of stock identification of haddock, Melanogrammus aeglefinus, in the northwest Atlantic Ocean. Mar Fish Rev 60:1-15

Bolz GR, Lough RG (1988) Growth through the first six months of Atlantic cod, Gadus morhua, and haddock, Melanogrammus aeglefinus, based on daily otolith increments. Fish Bull 86:223-235

Brickman D (2003) Controls on the distribution of Browns Bank juvenile haddock. Mar Ecol Prog Ser 263:235-246

* Brickman D, Shackell NL, Frank KT (2001) Modelling the retention and survival of Browns Bank haddock larvae using an early life stage model. Fish Oceanogr 10:284-296

*Bisson-Curadeau E, Patterson A, Whelan S, Lazarus T, Elliott KH (2017) Tracking Cairns: biologging improves the use of seabirds as sentinels of the sea. Front Mar Sci $4: 357$

* Brodziak J, O'Brien L (2005) Do environmental factors affect recruits per spawner anomalies of New England groundfish? ICES J Mar Sci 62:1394-1407

Brodziak JKT, Overholtz WJ, Rago PJ (2001) Does spawning stock affect recruitment of New England groundfish? Can J Fish Aquat Sci 58:306-318

Budge SM, Iverson SJ, Bowen WD, Ackman RG (2002) Among-and within-species variability in fatty acid signatures of marine fish and invertebrates on the Scotian Shelf, Georges Bank, and southern Gulf of St. Lawrence. Can J Fish Aquat Sci 59:886-898

* Burke CM, Montevecchi WA (2008) Fish and chicks: forage fish and chick success in co-existing auks. Waterbirds 31: 372-384

Cairns DK (1988) Seabirds as indicators of marine food supplies. Biol Oceanogr 5:261-271 
Cairns DK, Gaston AJ, Huettmann F (2008) Endothermy, ectothermy and the global structure of marine vertebrate communities. Mar Ecol Prog Ser 356:239-250

Christensen NL, Bartuska AM, Brown JH, Carpenter S and others (1996) Report of the Ecological Society of America Committee on the Scientific Basis for Ecosystem Management. Ecol Appl 6:665-691

* Cunningham JT, Elliott KH, Cottenie K, Hatch SA, Jacobs SR (2018) Individual foraging location, but not dietary, specialization: implications for rhinoceros auklets as samplers of forage fish. Mar Ecol Prog Ser 605:225-240

Cury PM, Boyd IL, Bonhommeau S, Anker-Nilssen T and others (2011) Global seabird response to forage fish depletion - one-third for the birds. Science 334:1703-1706

Davoren GK, Montevecchi WA (2003) Signals from seabirds indicate changing biology of capelin stocks. Mar Ecol Prog Ser 258:253-261

Deguchi T, Watanuki Y, Niizuma Y, Nakata A (2004) Interannual variations of the occurrence of epipelagic fish in the diets of the seabirds breeding on Teuri Island, northern Hokkaido, Japan. Prog Oceanogr 61:267-275

* Diamond AW, Devlin CM (2003) Seabirds as indicators of changes in marine ecosystems: ecological monitoring on Machias Seal Island. Environ Monit Assess 88:153-181

Einoder LD (2009) A review of the use of seabirds as indicators in fisheries and ecosystem management. Fish Res 95: $6-13$

Elliott KH, Davoren GK, Gaston AJ (2008a) Sources of bias in observations of Murre provisioning behavior. J Field Ornithol 79:298-307

Elliott KH, Woo K, Gaston AJ, Benvenuti S, Dall'Antonia L, Davoren GK (2008b) Seabird foraging behaviour indicates prey type. Mar Ecol Prog Ser 354:289-303

Emlen JM (1966) The role of time and energy in food preference. Am Nat 100:611-617

Field JC, Dick EJ, Key M, Lowry M and others (2007) Population dynamics of an unexploited rockfish (Sebastes jordani) in the California Current. In: Heifetz J, DiCosimo J, Gharrett AJ, Love MS, O'Connell VM, Stanley RD (eds) Biology, assessment, and management of North Pacific rockfishes. Alaska Sea Grant College Program, Anchorage, AK, p 451-472

Finley M, Wang Y, Stone HH (2018) Assessment of 4X5Y haddock (Melanogrammus aeglefinus) in 2016. Fisheries and Oceans Canada. Can Sci Advis Sec Res Doc 2018/041

Flanders Marine Institute (2018) Maritime Boundaries Geodatabase: Maritime Boundaries and Exclusive Economic Zones (200NM), version 10. https://doi.org/10.14284/312

Fox J, Weisberg S (2011) car: Companion to applied regression. R package version 3.0-2. https://CRAN.R-project. org $/$ package $=$ car

Francis RC, Hixon MA, Clarke ME, Murawski SA, Ralston S (2007) Ten commandments for ecosystem-based fisheries scientists. Fisheries 32:217-233

Frederiksen M, Elston DA, Edwards M, Mann AD, Wanless S (2011) Mechanisms of long-term decline in size of lesser sandeels in the North Sea explored using a growth and phenology model. Mar Ecol Prog Ser 432:137-147

Friedland KD, Hare JA, Wood GB, Col LA and others (2008) Does the fall phytoplankton bloom control recruitment of Georges Bank haddock, Melanogrammus aeglefinus, through parental condition? Can J Fish Aquat Sci 65: 1076-1086

Friedland KD, Leaf RT, Kristiansen T, Large SI (2015) Layered effects of parental condition and larval survival on the recruitment of neighboring haddock stocks. Can J Fish Aquat Sci 72:1672-1681

Hall CS (1999) The diet, reproductive performance, and management of common and Arctic terns in the Gulf of Maine. MSc thesis, University of Massachusetts, Amherst, MA

*Hatch SA, Sanger GA (1992) Puffins as samplers of juvenile pollock and other forage fish in the Gulf of Alaska. Mar Ecol Prog Ser 80:1-14

Hazen EL, Abrahms B, Brodie S, Carroll G and others (2019) Marine top predators as climate and ecosystem sentinels. Front Ecol Environ 17:565-574

Holling CS (1966) The functional response of invertebrate predators to prey density. Mem Entomol Soc Can 98(S48):5-86

Kassambara A, Mundt F (2017) factoextra: Extract and visualize the results of multivariate data analyses. $\mathrm{R}$ package version 1.0.5. https://CRAN.R-project.org/package=facto extra

Kelly GF, Barker AM (1961) Vertical distribution of young redfish in the Gulf of Maine. Int Comm Northwest Atl Fish Spec Publ 3:263-275

* Kleisner KM, Fogarty MJ, McGee S, Hare JA, Moret S, Perretti CT, Saba VS (2017) Marine species distribution shifts on the US Northeast Continental Shelf under continued ocean warming. Prog Oceanogr 153:24-36

Kress S, Shannon P, O'Neal C (2016) Recent changes in the diet and survival of Atlantic puffin chicks in the face of climate change and commercial fishing in midcoast Maine, USA. Facets 1:27-43

Kapolla A, Buckley LJ (2005) Hatch date distributions of young-of-year haddock Melanogrammus aeglefinus in the Gulf of Maine/Georges Bank region: implications for recruitment. Mar Ecol Prog Ser 290:239-249

* Lavoie RA, Rail JF, Lean DR (2012) Diet composition of seabirds from Corossol Island, Canada, using direct dietary and stable isotope analyses. Waterbirds 35:402-420

Leaf RT, Friedland KD (2014) Autumn bloom phenology and magnitude influence haddock recruitment on Georges Bank. ICES J Mar Sci 71:2017-2025

Legault CM, Restrepo VR (1998) A flexible forward agestructured assessment program. Collect Vol Sci Pap ICCAT 49:246-253

Legendre P, Gallagher ED (2001) Ecologically meaningful transformations for ordination of species data. Oecologia 129:271-280

* Lenth R, Singmann H, Love J, Buerkner P, Herve M (2019) emmeans: Estimated marginal means, aka least-squares means. R package version 1.3.4. https://CRAN.R-project.org $/$ package $=$ emmeans

* Lough RG, Valentine PC, Potter DC, Auditore PJ, Bolz GR, Neilson JD, Perry RI (1989) Ecology and distribution of juvenile cod and haddock in relation to sediment type and bottom currents on eastern Georges Bank. Mar Ecol Prog Ser 56:1-12

* Mayo RK, Burnett J, Smith TD, Muchant CA (1990) Growthmaturation interactions of Acadian redfish (Sebastes fasciatus) in the Gulf of Maine-Georges Bank region of the Northwest Atlantic. ICES J Mar Sci 46:287-305

* Miller D, Colton JB Jr, Marak RR (1963) A study of the vertical distribution of larval haddock. ICES J Mar Sci 28: $37-49$

Miller TJ, Mayo RK, Traver ML, Col LA (2008) N. Gulf of Maine/Georges Bank Acadian redfish in Assessment of 19 Northeast Groundfish Stocks through 2007: Report of the 3rd Groundfish Assessment Review Meeting (GARM III), 
Northeast Fisheries Science Center, Woods Hole, Massachusetts, August 4-8, 2008. US Dept Commer, NOAA Fisheries, Northeast Fish Sci Cent, Ref Doc 08-15

Mills KL, Laidig T, Ralston S, Sydeman WJ (2007) Diets of top predators indicate pelagic juvenile rockfish (Sebastes spp.) abundance in the California Current System. Fish Oceanogr 16:273-283

Morse WW, Fahay MP, Smith WG (1987) MARMAP surveys of the Continental Shelf from Cape Hatteras, North Carolina to Cape Sable, Nova Scotia (1977-1984). Atlas No. 2. Annual distributional patterns of fish larvae. NOAA Tech Memo NMFS-F/NEC-47

NAFO (Northwest Atlantic Fisheries Organization) (2015) NAFO Divisions (.shp). Open Government LicenseCanada. www.nafo.int/Data/GIS

NEFSC (Northeast Fisheries Science Center) (2014) Gulf of Maine Haddock Benchmark Stock Assessment for 2014. In: 59th Northeast Regional Stock Assessment Workshop (59th SAW) Stock Assessment Report. US Dept Commer, NOAA Fisheries, Northeast Fish Sci Cent, Ref Doc 14-09

NEFSC (2017) Operational Assessment of 19 Northeast Groundfish Stocks, updated through 2016. US Dept Commer, NOAA Fisheries, Northeast Fish Sci Cent, Ref Doc 17-17

NOAA Fisheries (2019) Species Information System public portal. www.st.nmfs.noaa.gov/sisPortal/sisPortalMain.jsp

* Page FH, Frank KT (1989) Spawning time and egg stage duration in Northwest Atlantic haddock (Melanogrammus aeglefinus) stocks with emphasis on Georges and Browns Bank. Can J Fish Aquat Sci 46(S1):s68-s81

Penney RW, Evans GT (1985) Growth histories of larval redfish (Sebastes spp.) on an offshore Atlantic fishing bank determined by otolith increment analysis. Can J Fish Aquat Sci 42:1452-1464

Piatt JF, Harding AMA, Shultz M, Speckman SG, van Pelt TI, Drew GS, Kettle AB (2007) Seabirds as indicators of marine food supplies: Cairns revisited. Mar Ecol Prog Ser 352:221-234

Piatt JF, Arimitsu ML, Sydeman WJ, Thompson SA and others (2018) Biogeography of pelagic food webs in the North Pacific. Fish Oceanogr 27:366-380

Politis PJ, Galbraith JK, Kostovick P, Brown RW (2014) Northeast Fisheries Science Center bottom trawl survey protocols for the NOAA Ship Henry B. Bigelow. US Dept Commer, NOAA Fisheries, Northeast Fish Sci Cent, Ref Doc 14-06

Quan NT (1988) The prediction sum of squares as a general measure for regression diagnostics. J Bus Econ Stat 6: 501-504

R Core Team (2019) R: a language and environment for statistical computing. R Foundation for Statistical Computing, Vienna. www.r-project.org

Rose GA (2005) On distributional responses of North Atlantic fish to climate change. ICES J Mar Sci 62:1360-1374

Editorial responsibility: Thierry Boulinier, Montpellier, France

Reviewed by: 2 anonymous referees
Roworth E, Signell R (1998) Construction of digital bathymetry for the Gulf of Maine (gom_15.xyz). United States Geological Survey (USGS). https://pubs.usgs.gov/of/1998/ of98-801/bathy/data.htm

Scopel LC, Diamond AW, Kress SW, Hards AR, Shannon P (2018) Seabird diets as bioindicators of Atlantic herring recruitment and stock size: a new tool for ecosystembased fisheries management. Can J Fish Aquat Sci 75: 1215-1229

Scopel L, Diamond A, Kress S, Shannon P (2019) Varied breeding responses of seabirds to a regime shift in prey base in the Gulf of Maine. Mar Ecol Prog Ser 626:177-196

Sévigny JM, Méthot R, Bourdages H, Power D, Comeau P (2007) Review of the structure, the abundance and distribution of Sebastes mentella and S. fasciatus in Atlantic Canada in a species-at-risk context: an update. Fisheries and Oceans Canada, Can Sci Advis Sec, Res Doc 2007/085

Sherman K, Smith W, Morse W, Berman M, Green J, Ejsymont L (1984) Spawning strategies of fishes in relation to circulation, phytoplankton production, and pulses in zooplankton off the northeastern United States. Mar Ecol Prog Ser 18:1-19

Solomon ME (1949) The natural control of animal populations. J Anim Ecol 18:1-35

Spencer SM (2012) Diving behavior and identification of sex of breeding Atlantic puffins (Fratercula arctica), and nestsite characteristics of alcids on Petit Manan Island, Maine. MSc thesis, University of Massachusetts, Amherst, MA

Stephenson RL (1999) Stock complexity in fisheries management: a perspective of emerging issues related to population sub-units. Fish Res 43:247-249

Sydeman WJ, Piatt JF, Thompson SA, García-Reyes M and others (2017) Puffins reveal contrasting relationships between forage fish and ocean climate in the North Pacific. Fish Oceanogr 26:379-395

Symons SC (2018) Ecological segregation between two closely related species: exploring Atlantic puffin and razorbill foraging hotspots. MSc thesis, University of New Brunswick, Fredericton

* Szuwalski CS, Vert-Pre KA, Punt AE, Branch TA, Hilborn R (2015) Examining common assumptions about recruitment: a meta-analysis of recruitment dynamics for worldwide marine fisheries. Fish Fish 16:633-648

Trzcinski MK, Devred E, Platt T, Sathyendranath S (2013) Variation in ocean colour may help predict cod and haddock recruitment. Mar Ecol Prog Ser 491:187-197

*Valentin AE, Penin X, Chanut JP, Power D, Sévigny JM (2014) Combining microsatellites and geometric morphometrics for the study of redfish (Sebastes spp.) population structure in the Northwest Atlantic. Fish Res 154: 102-119

Velarde E, Ezcurra E, Anderson D (2015) Seabird diet predicts following-season commercial catch of Gulf of California Pacific Sardine and Northern Anchovy. J Mar Syst 146:82-88

Submitted: November 7, 2019

Accepted: October 13, 2020

Proofs received from author(s): November 24, 2020 